\title{
Koronavirüslerin moleküler yapısı ve tedavide kök hücre kullanımı
}

\section{Molecular structure of coronaviruses and stem cell use in treatment}

\author{
Meliz Sofu ${ }^{1}$ \\ Canberk Tomruk ${ }^{2}$ D \\ Hatice Kübra Başaloğlu ${ }^{3}$ \\ Emel Öykü Çetin Uyanıkgil ${ }^{4}$ D \\ Yiğit Uyanıkgil ${ }^{1,2,5}$ \\ ${ }^{1}$ Ege Üniversitesi, Sağlık Bilimleri Enstitüsü, Kök Hücre AD İzmir, Türkiye \\ ${ }^{2}$ Ege Üniversitesi, Tıp Fakültesi, Histoloji ve Embriyoloji AD İzmir, Türkiye \\ ${ }^{3}$ Aydın Adnan Menderes Üniversitesi, Tıp Fakültesi, Histoloji ve Embriyoloji AD İzmir, Türkiye \\ ${ }^{4}$ Ege Üniversitesi, Eczacılık Fakültesi, Biyofarmasötik ve Farmakokinetik Bilim Dalı, İzmir, Türkiye \\ ${ }^{5}$ Ege Üniversitesi Kordon Kanı, Hücre-Doku Araştırma ve Uygulama Merkezi, İzmir, Türkiye
}

\section{Öz}

Koronavirüsler ilk olarak 1930 'larda keşfedilmiştir. SARS ve MERS salgınlarından sonra ortaya çıkan COVID-19 pandemisi kısa sürede çok fazla enfeksiyon ve ölüme neden oldu. Koronavirüsler en büyük RNA genomuna sahip virüslerdir. İçerdiği glikoproteinlerden kaynaklı mikroskop altında taç görünümüne sahiptir. COVID-19 enfeksiyonunun spesifik semptomları olmamasına rağmen ateş, öksürük, balgam, miyalji ve baş ağrısı en belirgin semptomlarıdır. Teşhisinde en yaygın kullanılan yöntem PCR testidir. Henüz standart bir tedavisi bulunmayan COVID-19 enfeksiyonunda denenen tedavilerden biri de kök hücre tabanlı tedavilerdir.

Bu derlemede COVID-19'un genel epidemiyolojisi, genomik yapısı ve COVID-19 için kök hücre tedavilerinin önemi irdelenecektir.

Anahtar Sözcükler: Koronavirüs, pandemi, Kök hücre tedavisi.

\begin{abstract}
Coronaviruses were first discovered in the 1930s. The COVID-19 pandemic that emerged after the SARS and MERS outbreaks caused a lot of infections and deaths in a short time. Coronaviruses are viruses with the largest RNA genome. It has a crown appearance under the microscope due to the glycoproteins it contains. Although there are no specific symptoms of COVID-19 infection, fever, cough, sputum, myalgia and headache are the most prominent symptoms. The most widely used method in its diagnosis is the PCR test. One of the treatments tried in COVID-19 infection, for which there is no standard treatment yet, is stem cell-based therapies.

This review will examine the general epidemiology, genomic nature of COVID-19 and the importance of stem cell treatments for COVID-19.
\end{abstract}

Keywords: Coronavirus, pandemic, stem cell therapy.

\section{GiRiş}

Koronavirüsler (CoV'ler) ilk olarak 1930'larda tanımlanmış ve ilk kez 1960'larda elektron mikroskopik olarak görüntülenmiştir. CoV'ler birkaç istisnası dışında memelilerde ve kuşlarda solunum veya bağırsak enfeksiyonlarına neden olur.

\footnotetext{
Sorumlu yazar: Yiğit Uyanıkgil

Ege Üniversitesi, Tıp Fakültesi, Histoloji ve Embriyoloji AD İzmir, Türkiye

E-posta: yigituyanikgil@gmail.com

Başvuru tarihi: 21.03.2021 Kabul tarihi: 24.04.2021
} 
Yakın zamana kadar, altı farklı insan CoV ayırt edilmiştir ve bunların tümü esas olarak solunum sistemini enfekte etmektedir. $\mathrm{Bu}$ virüslerden HCoV-229E, HCoV-HKU1, HCoV-OC43 ve HCoVNL63, yıllık yaygın soğuk algınlığının yaklaşık \%10-15'inden sorumludur (1).

$\mathrm{Bu}$ virüs enfeksiyonları genellikle hafif seyrederken, Şiddetli Akut Solunum Sendromu (SARS)-CoV ve Orta Doğu Solunum Sendromu (MERS)-CoV enfeksiyonları için bu durum geçerli değildir, bu enfeksiyonlarda sırasıyla \%10 ve \%35 mortalite rapor edilmiştir (2).

SARS, Kasım 2002'de, Çin'in Guangdong şehrinde yeni bir betakoronavirüs olarak ortaya çıkmıştır ve yarattığı salgın 37 ülkede 8000 'den fazla enfeksiyon ve 774 ölümle sonuçlandı. 2012 yılında ilk olarak Suudi Arabistan'da saptanan MERS ise 2494 kişiyi etkilemiş ve 858 ölüme neden olmuştur (3). Daha sonra, ilk kez 12 Aralık 2019'da Çin'in Hubei eyaletinde Wuhan merkezli, sebebi bilinmeyen pnömoni vakaları ortaya çıkmaya başladı (4). Ocak 2020'ye kadar yapılan araştırmalar sonucunda pnömoni vakalarından alınan alt solunum yolu örneklerinde SARS-CoV2 virüsü tespit edilmiştir (5). 7 Ocak 2020'ye kadar, Çin Ulusal Viral Hastalık Kontrol ve Önleme Enstitüsü, SARS-CoV-2'nin genetik dizisini ve virüsün Wuhan'daki daha önce bildirilen pnömoni kümesiyle ilişkili olduğunu doğruladı (6). Yapılan gözlemler sonucunda, birincil hasta grubunun Wuhan'daki Huanan Güney Çin Deniz Ürünleri Pazarı ile bağlantılı olduğu bulundu (7). SARS-CoV-2'nin patlak vermesinden sonra, Çin Hükümeti, 26 Ocak 2020 tarihinde hastalığın yayılmasını önlemek için 1 . seviye halk sağlığı mücadelesi başlattı. 3 Mart 2020 (Pekin saati) 24:00 itibariyle SARS-CoV-2, Çin'de 80.270 laboratuvar ve klinik olarak doğrulanmış vaka ve 2981 hasta ölümüyle sonuçlandı (8).

$\mathrm{Bu}$ derlemede COVID-19'un genel epidemiyolojisi, genomik yapısı ve COVID-19 için kök hücre tedavilerinin önemi irdelenecektir.

\section{COVID-19 Virüsü}

Yüksek genetik çeşitlilik ve birden fazla konak türünü enfekte etme yeteneği, daha yüksek homolog RNA rekombinasyonu oranları ile birlikte RNA'ya bağı RNA polimerazların kararsızlığı nedeniyle ortaya çıkan CoV'ler yüksek frekanslı mutasyonların bir sonucudur (9). RNA virüslerinin değişen koşullara uyum sağlama ve yeni konakçıları istila etme konusunda olağanüstü yetenekleri bulunmaktadır ve genomlarını yüksek replikasyon hızlarıyla kopyalayabilmektedir. RNA virüslerinin genomları oldukça heterojendir ve genetik olarak ilgili varyantların dinamik popülasyonlarından oluşur ve aynı zamanda mutant suşlar olarak da bilinir. Bu sadece RNA virüslerinin yeni konakçı türlerini enfekte etmesine izin vermekle kalmaz, aynı zamanda bağışıklık denetiminden kaçmasına ve antiviral ilaçlara dirençli hale gelmesine de izin verir (10).

CoV'ler Coronaviridae (alt aile Coronavirinae) ailesine aittir, geniş bir konakçı yelpazesini enfekte edebilmektedir, soğuk algınlığından SARS, MERS ve şu anda COVID-19'da olduğu gibi şiddetli ve ölümcül hastalıklara kadar değişen semptom ve hastalıklar üretebilmektedir. Koronavirüs hastalığı-19 (COVID-19), Şiddetli Akut Solunum Sendromu Koronavirüsü-2 (SARSCoV-2) olarak adlandırılan yeni bir koronavirüsten kaynaklanır. CoV'lerin öncelikle kuşlar ve memelilerde enzootik enfeksiyonlara neden olduğu düşünülüyordu. SARS, MERS ve şimdi COVID-19 salgınları CoV'lerin tür engellerini aşma ve insanlar arasında bulaşma konusundaki olağanüstü yeteneğini açıkça göstermiştir (11). COVID-19 (SARS-CoV-2), insanları enfekte eden CoV ailesinin yedi üyesinden biri olarak kabul edilir. COVID-19, SARS'a neden olan aynı CoV soyuna aittir, ancak genetik olarak SARS'tan farklıdır (12). SARS-CoV-2, Nidovirales takımının bir üyesidir, Coronaviridae ailesi, Orthocoronavirinae alt ailesi, Alphacoronavirus, Betacoronavirus, Gammacoronavirus ve Deltacoronavirus diye bilinen dört cinse ayrılmıştır. Alphacoronavirus ve Betacoronavirus cinsleri yarasalardan kaynaklanırken, Gammacoronavirus ve Deltacoronavirus kuşlar ve domuz kaynaklıdır (13). Koronavirüs doğal ve zootonik bir kökene sahiptir. COVID-19'un kökeni zoonotik transferden önce bir hayvan konakçıda doğal seleksiyon veya zoonotik transferin ardından insanlarda doğal seleksiyon olmak üzere iki şekilde açıklanmıştır.

Moleküler karakterizasyona dayalı olarak, SARSCoV-2, Sarbecovirus alt cinsine ait yeni bir Betacoronavirüs olarak kabul edilir. Diğer birkaç zoonotik virüs (MERS ile ilgili CoV ve SARS ile ilgili CoV) de aynı cinse aittir. Yapısal genlerin filogenetik analizi, SARS-CoV-2'nin yarasalardan (yarasa-SL-CoVZC45 ve yarasa-SL-CoVZXC21) türetilen SARS benzeri iki CoV ile yakından ilişkili olduğunu ortaya çıkarmıştır. Ayrıca, SARS-CoV-2 
genetik olarak SARS-CoV (\%79) ve MERS-CoV (\%50) ile benzerdir (14). Genomik çalışma yoluyla, SARS-CoV-2 ve SARS-CoV'nin insanda aynı hücre reseptörünü paylaştığı, MERSCoV'nin ise insan hücrelerine girmek için dipeptidil peptidaz 4'ü (DPP4) kullandığı tespit edilmiştir (15). SARS-CoV-2 yarasalardan kaynaklanmış olabilirken, diğer amplifikatör konaklar bu hastalığın insanlara bulaşmasında olası bir rol oynamış olabilir. Diğer iki zoonotik CoV (MERS ve SARS) da yarasalardan kaynaklanmıştır (16).

CoV kabaca küreseldir, 120-160 nm çapa sahiptir ve koruyucu bir kılıf veya zarfla çevrili bir çekirdekten (nükleokapsid olarak da adlandırılır) oluşur. Koronavirüsler, bir 5'-cap ve 3'-poly-A kuyruğu ile çevrili, yaklaşık 30 kb'lik bölünmemiş, pozitif sarmallı tek iplikli en büyük RNA genomuna sahiptir. SARS-CoV-2'nin genomu $29.891 \mathrm{~kb}$ uzunluğundadır ve G (\%32) + C (\%43) içerikleri vardır (17). Çok uzun bir mRNA [(+) gRNA] olan CoV genomu hücre içinde serbest bırakıldıktan sonra, pp1a ve pp1ab olarak adlandırılan iki büyük poliprotein üretmek üzere hemen çevrilir. Viral RNA'dan başlayarak, konakta poliprotein 1a/1ab (pp1a/pp1ab) sentezi gerçekleştirilir. Transkripsiyon, çift membranlı veziküllerde organize edilen replikasyontranskripsiyon kompleksi (RCT) ve subgenomik RNA (sgRNA) sekanslarının sentezi yoluyla çalışır. Transkripsiyonun sonlanması, subgenomik mRNA'ların üretimi için şablonlar olarak çalışan açık okuma çerçeveleri (ORF'ler) arasında yer alan transkripsiyon düzenleyici dizilerde meydana gelir. Atipik CoV genomunda en az altı ORF mevcut olabilir (18). Hücre girişi üzerine genomik RNA ORF1a ve ORF1b'den yapısal olmayan proteinler (nsps) üretmek üzere çevrilir.

Viral genom, RNA'ya bağlı RNA polimeraz (RdRP) aktivitesini barındıran nsp12'nin aracılık ettiği replikasyon ve transkripsiyon için şablon olarak kullanılır. Negatif duyarlı RNA ara ürünleri, pozitif duyarlı genomik RNA (gRNA) ve alt genomik RNA'ların (sgRNA'lar) sentezi için şablon olarak fonksiyon görür. Korunmuş yapısal proteinleri spike protein [S], zarf proteini [E], membran proteini $[\mathrm{M}]$ ve nükleokapsid proteini [N]) ve birkaç yardımcı protein sgRNA'lar tarafından kodlanır. Farklı CoV'ler, sgRNA'ların translasyonları ile özel yapısal ve yardımcı proteinler oluşturur. CoV'lerin ve dolayısıyla SARS-CoV-2'nin patofizyolojisi ve virülans mekanizmaları, nsps ve yapısal proteinlerin işleviyle bağlantılara sahiptir. Araştırmalar nsps'nin konağın humoral bağışıklık yanıtını bloke edebildiğini göstermiştir. Virüsün zarf proteini, viral birleşmeyi ve salımı teşvik ettiği için virüs patojenitesinde önemli bir role sahiptir (19). CoV'lerin yardımcı proteinleri, virüsün yararına çeşitli hücresel işlevlerin düzenlenmesinde yer alır. Çoğu yardımcı protein birden fazla işlevi yerine getirir ve bunların bir çoğu küçük yapısal proteinler olarak virüs partiküllerine dahil edilir. $\mathrm{N}$ proteini, yeni sentezlenen pozitif iplikli RNA'ları bağlar. Elde edilen ribonükleoprotein kompleksleri (yani nükleokapsidler), S, M ve $\mathrm{E}$ proteinlerinin yerleştiği endoplazmik retikulum (ER)-Golgi ara bölmesindeki (ERGIC) membranları ile birleşir. Virüs partikülleri, kapsidlerin ERGIC membranlarından tomurcuklanmasıyla oluşturulur ve daha sonra veziküller (yani eksozomlar) içinde hücre yüzeyine taşınır, burada plazma membranı ile birleşerek hücre dışı boşluğa virüs partiküllerinin salınmasına yol açar. Oradan da daha fazla virüs üretimini tetiklemek üzere yeni hedef hücrelere yayılabilirler (20).

Pnömoni üreten patolojik mekanizmalar oldukça karmaşıktır. Şimdiye kadar mevcut veriler, viral enfeksiyonun konakçıda aşırı bir bağışıklık reaksiyonu üretebildiğini göstermektedir. Bazı durumlarda, "sitokin fırtınası" olarak adlandırılan bir reaksiyon gelişir ve yaygın doku hasarına yol açar. Sitokin fırtınasının sorumlusu interlökin 6'dır (IL-6). IL-6, aktive edilmiş lökositler tarafından üretilir ve çok sayıda hücre ve doku üzerinde etkilidir (21). B lenfositlerin farklılaşmasını teşvik edebilir, bazı hücrelerin büyümesini desteklerken bazılarının büyümesini engeller. Ayrıca akut faz proteinlerinin üretimini uyarır ve termoregülasyon, kemik bakımı ve merkezi sinir sisteminin işlevselliğinde önemli bir rol oynar. IL-6'nın oynadığı ana rol proinflamatuvar olmakla birlikte, antiinflamatuvar etkilere de sahip olabilir. IL-6, inflamatuvar hastalıklar, enfeksiyonlar, otoimmün bozukluklar, kardiyovasküler hastalıklar ve bazı kanser türlerinde artar. Ateş ve çoklu organ disfonksiyonu ile karakterize akut sistemik inflamatuvar bir sendrom olan sitokin salıverilme sendromunun (CRS) patogenezinde de rol oynamaktadır (22).

Virüs, özellikle nazal ve faringeal mukoza olmak üzere mukoza zarlarından geçebilir, ardından akciğerlere girer. Daha sonra, akciğerler, kalp, böbrek sistemi ve gastrointestinal sistem gibi 
anjiyotensin dönüştürücü enzim 2'yi (ACE2) eksprese eden hedef organlara saldırır. Virüs hastanın durumunun başlangıcından yaklaşık 7 ile 14 gün sonra kötüleşmesine neden olur. Hastalığın erken döneminde B lenfosit azalması meydana gelebilir ve bu da hastada antikor üretimini etkileyebilir. Bunun yanı sıra, esas olarak IL-6 içeren hastalıklarla ilişkili inflamatuvar faktörler önemli ölçüde artarak ve hastalığın başlangıcından yaklaşık 2 ila 10 gün sonra şiddetlenmesine katkıda bulunur (23).

İmmün aracılı inflamatuvar belirteçler, interlökin (IL)-2,-6,-7, monosit kemoatraktan protein-1 ve tümör nekroz faktörü alfa (TNF-a), COVID-19 patogenezinde önemli bir rol oynar. $\mathrm{Bu}$ inflamatuvar sitokinlerin akciğer dokularına alınması ödem, akciğer disfonksiyonu ve akut solunum sıkıntısı sendromuna (ARDS) neden olur, bu da ölüme yol açabilir. COVID-19 gelişimine lenfositlerde düşüş ve nötrofil sayılarında önemli bir artış eşlik eder, özellikle şiddetli enfeksiyonu olan hastalarda B hücreleri, $T$ hücreleri ve doğal öldürücü $(\mathrm{NK})$ hücrelerin sayısı azalır (24).

Koronavirüs için önemli olan 4 yapısal protein bulunmaktadır; Spike protein (S), Membran protein $(\mathrm{M})$, Nükleoplazmid $(\mathrm{N})$ ve Zarf Protein (E).

\section{Spike protein (S)}

Koronavirüs $S$ proteini, büyük bir çok fonksiyonlu sınıf I viral transmembran proteinidir. S proteininin boyutu 1160 amino asitten (kümes hayvanlarında IBV, Enfeksiyöz Bronşit Virüsü) 1400 amino aside (FCoV, Feline Coronavirus) kadar değişebilmektedir. Elektron mikroskobunda incelendiğinde taç benzeri bir görünüme sahiptir. Fonksiyonel olarak enfeksiyöz virion partiküllerinin çeşitli konakçı hücresel reseptörlerle etkileşim yoluyla hücre içine girmesi gerekir (25).

$S$ proteini, virüsün hedef hücrelere bağlanmasında rol oynar ve zar füzyonuna aracılık ederek bu hücrelerin penetrasyonunda çok önemli bir role sahiptir. SARS-CoV-2 partiküllerinin hücresel reseptör anjiyotensin I dönüştürücü enzim 2'ye (ACE2) bağlanmasından ve $S$ proteininin transmembran serin proteaz 2 (TMPRSS2) ile bölünmesinden sonra, viral zarf, hedef hücrenin plazma zarı ile birleşerek viral genomun hücre içinde taşınmasına neden olur. Alternatif olarak, $S$ proteinlerinin ACE2'ye bağlanması üzerine, SARS-CoV-2 hedef hücre tarafından endozom adı verilen küçük veziküller içinde alınır. Daha sonra, S proteini, viral zarfın endozomun lipit çift tabakası ile füzyonunu başlatan ve viral genomun hücrenin sitoplazması içine salınmasına neden olan endozomal proteaz katepsin L tarafından bölünür (26).

\section{Membran protein (M)}

$M$ proteini, virion partikülünde en çok bulunan viral proteindir ve viral zarfa şekil verir. Nükleokapside bağlanır ve koronavirüs yapısının merkezi düzenleyicisi olarak işlev görür. Koronavirüslerdeki $\mathrm{M}$ proteinleri, amino asit içerikleri açısından oldukça çeşitlidir, ancak genel olarak yapısal benzerliğe sahiptir. $M$ proteini, virionun dışında kısa aminoterminal ile çevrili üç transmembran alanına ve virion içinde uzun bir karboksi terminaline sahiptir. Genel olarak, viral yapı iskelesi M-M etkileşimi ile korunur (27).

\section{Zarf protein (E)}

Koronavirüs $\mathrm{E}$ proteini, ana yapısal proteinler arasında en küçük olanıdır. Virüsün patogenezinde, tutunması ve salınmasında çok işlevli bir rol oynar. Viroporin (iyon kanalı) gibi davranan küçük bir entegre membran polipeptididir. $\mathrm{Bu}$ proteinin inaktivasyonu veya yokluğu, morfoloji ve tropizmdeki değişiklikler koronavirüslerin virülansını değiştirir. $\mathrm{E}$ proteini, kısa hidrofilik amino terminali, büyük bir hidrofobik transmembran alanı ve bir $\mathrm{C}$ terminal alanı olmak üzere üç alandan oluşur (28).

\section{Nükleoplazmid protein (N)}

Koronavirüsün $\mathrm{N}$ proteini çok amaçlıdır. Viral genomdaki karmaşık işlevlerde rol alır, virion montajı sırasında intiyaç duyulan $M$ protein etkileşimini kolaylaştırır ve virüsün transkripsiyon etkinliğini artıır. Bir N-terminal alanı (NTD), RNA bağlama alanı veya bir bağlayıcı bölge (LKR) ve bir C-terminal alanı (CTD) içerir. NTD, viral genomun 3' ucuna, elektrostatik etkileşimler yoluyla bağlanır ve hem uzunluk hem de sekans açısından oldukça farklıdır. Yüklü LKR serin ve arginin açısından zengindir ve ayrıca SR (Serin ve Arginin) alanı olarak da bilinir. LKR bölgesi hücre sinyallemesinden sorumludur, interferon ve RNA interferansı için bir antagonist olarak çalışarak konakçının antiviral yanıtını modüle eder (29).

\section{Covid-19 Tedavisinde kök hücreler}

Mezenkimal kök hücrelerin (MKH) akut akciğer hasarının önlenmesinde çeşitli mekanizmalar yoluyla işlev gördüğü bilinmektedir. MKH'lerin 
intravenöz infüzyonunun akciğerlerde biriktiği bilinmektedir; çok sayıda parakrin faktör salgılayarak alveolar fibrozise karşı epitel hücrelerinin korunmasında önemli bir rol oynarlar (30).

Çeşitli çalışmalar, MKH'lerin hem humoral hem de edinsel immün yanıtı doğrudan hücre-hücre teması ve trofik faktörler aracılığıyla düzenlediğini göstermiştir. COVID-19 hastalarının, özellikle ağır vakalarda, azalmış düzenleyici $\mathrm{T}$ hücre (Treg) sayılarına sahip olduğu gösterilmiştir (31). MKH'ler ve özellikle adipoz kaynaklı mezenkimal kök hücreler (AKMKH) Treg oluşumunu arttırır. AKMKH'lerin Treg'lerin gelişimini kemik iliği kaynaklı MKH'lerden veya Wharton jeli kaynaklı MKH'lerden (WJ-MSC) daha etkili bir şekilde desteklediği gösterilmiştir. AKMKH'nin dendritik hücre farklılaşmasının immünomodülasyonunda kemik iliği kaynaklı MKH'lerden daha etkili olduğu gösterilmiştir $(32,33)$.

\section{MKH'lerin terapötik etki mekanizmaları}

\section{Antiinflamatuvar}

MKH uygulaması, birçok akut akciğer hasarı modelinde antiinflamatuvar etkiler göstermiştir (34).

\section{Antibakteriyel}

MKH'ler, hem in vitro hem de küçük hayvan modellerinde gösterilen antimikrobiyal özelliklere sahiptir. MKH'lerin makrofajları proinflamatuvar durumdan antiinflamatuvar fenotipe yeniden programlarken fagositik aktivitesini artırdığı gösterilmiştir (35).

\section{Antiviral}

MKH'ler viral replikasyonu, viral bulaş ve virüsün indüklediği akciğer epitel hücresi (LEC) hasarını baskılar. Khatri ve arkadaşları., MKH kaynaklı hücre dışı veziküllerin (MKH-EV'ler), RNA'ların EV'lerden LEC'lere aktarılması yoluyla hem antiinflamatuvar hem de antiviral özellikleri arttırdığını gösterdi (36).

\section{Akciğer fibrozisi inhibisyonu ve akciğer dokusu yenilenmesi}

Fibroblast ve miyofibroblast birikimi, epitelyal doku onarımı sırasında gelişir. Artmış hücresel matriks protein sentezi; düşük doku kompliyansı, akciğer parankim hasarı oluşturur ve uzun vadede fonksiyon kaybına yol açar. Akciğerdeki nötrofil ve makrofaj artışı, fibroblastlardan kollajen salınımını teşvik eden profibrotik proteinleri aktive eder. Fibrotik akciğer hastalığı olan hastalardan elde edilen akciğer dokusu, çok sayıda MKH içermektedir. Hayvan modelleri, inflamasyonu iyileştirmek ve orta derecede fibrozisli akciğer dokusunun remodelingi için erken uygulandığında MKH'lerin olumlu etkilerini göstermiştir (37).

\section{Alveolar sıvı klirensi}

Alveolar tip II (ATII) hücreler, alveolar yüzey alanının yaklaşık \%2-5'ini oluşturur ve sürfaktan üreten bu hücreler alveolar epitel için progenitör hücreler olarak işlev görürler. ARDS'li hastalarda, daha yüksek morbidite ve mortalite ile ilişkili olan bozulmuş alveolar sıvı klirensi vardır. Çok sayıda çalışma, MKH'lerin sodyum ve klorür iyon kanalları ile etkileşiminin alveolar sıvı klirensini artırdığını ve pulmoner ödemin çözülmesini teşvik ettiğini doğrulamaktadır (38).

\section{Hücre dışı vezikül üretimi}

MKH'lerin akut akciğer hasarını iyileştirmeye yardımcı olabilecek hücre dışı veziküller (EV'ler) ürettiğini göstermektedir. EV'ler eksozomlar, mikroveziküller (MV'ler) ve apoptotik cisimler içerir. MV'ler doğrudan hücre membranından tomurcuklanarak oluşur. Selektinler, integrinler, CD-40, fosfatidilserin ve metaloproteinazlar da bol miktarda bulunurlar. (39).

Hücre temelli tedaviler ve özellikle kök hücre tedavisi, pek çok tedavisi olmayan hastalıkta denenen umut verici bir terapötik alan haline gelmiştir. Kök hücre temelli tedavi alanındaki önemli gelişmelere rağmen, bu terapötik yaklaşımın ana sınırlamaları olan immünojenisite, sınırlı hücre kaynağı ve etik sorunlar henüz çözülmemiştir. Bunlar arasında, MKH'ler kaynak potansiyeli, yüksek proliferasyon oranı, düşük invaziv uygulama prosedürleri ve etik sorunlardan uzak olması nedeniyle dikkat çekmiştir (40).

Mezenkimal kök hücreler; kuş gribi H9N2 gibi bulaşıcı hastalıklar, hepatit virüsleri $B$ ve $C$ enfeksiyonları ve insan immün yetmezlik virüsü (HIV) enfeksiyonu gibi birçok hastalık için hücre temelli tedavilerde umut vericidir. MKH'lerin COVID-19 tedavisinde immün hücrelerin immünomodülasyonu, inflamasyonu azaltma ve hasarlı akciğer dokularının rejenerasyonuna katkıları ile rol alabilecekleri düşünülmüştür.

Mezenkimal kök hücreler güçlü immünmodülatör yeteneklerinden dolayı sitokin fırtınasını önlemede veya hafifletmede ve böylece hastalığın morbidite ve mortalitesini azaltmada yararlı etkilere sahip olabilir (41). MKH'ler, parakrin sekresyonu ile birçok sitokin türünü salgılayabilir veya $\mathrm{T}$ hücreleri, $\mathrm{B}$ hücreleri, 
dendritik hücreler, makrofajlar ve immünmodülasyona yol açan doğal öldürücü hücreler dahil olmak üzere immün hücreler ile doğrudan etkileşimler yapabilir. Kök hücrelerin inflamatuvar yanıtı düzenlediği ve doku onarımını ve yenilenmesini desteklediği düşünülmektedir. MKH'lerin ayrıca kardiyovasküler, renal, hepatik ve diğer birçok bozuklukta işlevi iyileştirdiği gösterilmiştir (37).

MKH tedavisi teorik olarak bağışıklık sisteminin aşırı aktivasyonunu inhibe edebilir ve mikroçevreyi iyileştirerek endojen onarımı destekleyebilir. Intravenöz infüzyon yoluyla insan vücuduna girdikten sonra, MKH'lerin bir kısmı akciğerde birikir ve bu da potansiyel olarak pulmoner mikroçevreyi iyileştirebilir, alveolar epitel hücrelerini koruyabilir, pulmoner fibrozu önleyebilir ve akciğer fonksiyonunu iyileştirebilir $(37,42)$. Bununla birlikte, bu yaklaşımdaki ana kısıtlamalardan biri, klinik dereceli MKH'lerin tedarik kaynağı ve ardından burada kök hücre bankalarının önemli bir rol oynayabileceği klinik kullanıma hazırlık hızıdır. Ayrıca MKH'ler, tercihen kemik iliği, periferik kan ve adipoz dokular (abdominal yağ, infrapatellar yağ pedi ve bukkal yağ pedi gibi) gibi yetişkin dokuları ile doğumla iliş̧ili dokular olan plasenta, umbilikal kord, Wharton jeli, amniyotik sıvı ve kordon kanı kaynaklı olabilir, doğumda elde edilen bu dokulardan elde edilen kök hücreler gelecekteki olası uygulamalar için saklanabilir. Bu nedenle, MKH'ye dayalı terapi muhtemelen klinik araştırmalar için ideal bir aday veya COVID-19 hastalarını tedavi etmek için tedavi kombinasyonlarında yer alabilecek bir modalite olabilir (43).

\section{COVID-19 Kök Hücre Klinik Çalışmaları}

Antiinflamatuvar ve immünmodülatör özelliklerinden dolayı, otojen veya allojenik ve farklı kökenlere sahip MKH'ler, COVID-19 pandemisinden önce çok sayıda şiddetli solunum yolu hastalığını tedavi etmek için kullanılmıştır. Önceki çalışmalar, MKH tedavisinden sonra uzun süreli solunum fonksiyonunun korunmasıyla birlikte advers olayların olmadığını ve solunum fonksiyonunun iyileştiğini bildirmiştir (44).

COVID-19 ilk kez yakın zamanda bildirilmesine rağmen, $\mathrm{MKH}$ tedavisi üzerine birkaç klinik çalışma yayınlanmıştır. Liang ve ark. (45) SARSCoV-2 ile enfekte olan 65 yaşındaki kritik derecede hasta bir kadının tedavisini bildirdi. Yorgunluk, ateş ve öksürük ile başvuran hastada ertesi gün göğüste sıkışma, hipoksi ve hipertansiyon gelişti ve COVID-19 testi pozitif çıktı. Radyografilerde buzlu cam opasitesi görüldü ve 2 gün sonra hastaneye kaldırıldı. Başlangıçta antiviral tedavi (lopinavir / ritonavir), IFN-y inhalasyonu, oseltamivir ve IV moksifloksasin, Xuebijing, metilprednizolon ve immünoglobulin enjeksiyonu ile tedavi edildi. Solunumu noninvaziv mekanik ventilatör ile sağlandı. Günler sonra akut solunum yetmezliği olan hasta ventilatör desteği için YBÜ'ye transfer edildi. Sonunda glukokortikoid ve antiviral tedaviler geri çekildi ve 1 hafta sonra $50 \times 10^{6}$ allojenik göbek kordonu-MKH'ler i.v. olarak uygulandı. Hiçbir belirgin yan etki kaydedilmedi. Tedavi, ilk tedaviden 3 ve 6 gün sonra tekrarlandı. Üçüncü dozunun infüzyonundan iki gün sonra, normal yaşamsal belirtiler ve laboratuvar değerleri ve COVID-19 antijeni için negatif bir boğaz sürüntü testi ile yoğun bakımdan çıkarıldı. Bu çalışma sadece kritik hastalığı olan bir hasta ile sınırlı olmasına rağmen, elde edilen olumlu sonuç daha fazla araştırmayı desteklemektedir. Leng ve ark. (43), COVID-19'lu yedi hastaya i.v. göbek kordonu$\mathrm{MKH}$ uygulamasında benzer gelişmeler bildirdi. Seçilen hastalar SARS-CoV-2 için pozitifti, biri kritik derecede şiddetli hastalığa sahipken, dört şiddetli ve ikisi daha hafif hastalık semptomları gösteren hasta bulunmaktaydı. Plasebo kontrolü için şiddetli tipte üç hasta daha kaydedildi. MKH infüzyonundan önce tüm hastalarda yüksek ateş, nefes darlığı, düşük oksijen satürasyonu ve pnömoni görüldü. Semptomlar kötüleştiğinde, hastalar intravenöz olarak $1 \times 10^{6}$ göbek kordonu$\mathrm{MKH} / \mathrm{kg}$ aldı ve 14 gün boyunca yakından takip edildi. Hemen hemen tüm semptomlar, MKH infüzyonlarını izleyen 2-4 gün içinde hiçbir yan etki olmaksızın azalmıştır. Toraks BT görüntülemesinde pnömoni infiltrasyonunun önemli ölçüde azaldığı görülmüştür. Hastaların çoğu, MKH infüzyonundan bir veya iki hafta sonra SARS-CoV-2 nükleik asit testi için negatif çıkmıştır. Böylece MKH'nin, herhangi bir yan etki gözlemlenmeksizin 7 hastanın fonksiyonel sonuçlarını önemli ölçüde iyileştirebildiğini gösteren bu çalışma oldukça önemlidir. Kısa vadeli yan etki gözlemlenmemiş olmasına rağmen, $\mathrm{MKH}$ uygulamasından sonra uzun vadeli takip gelecekteki klinik çalışmalarda gerekli olacaktır. MKH infüzyonundan sonra iyileşmenin altında yatan mekanizmalar, güçlü antiinflamatuvar aktivitenin sonucu gibi görünmektedir (46). 


\section{SONUÇ}

Aralık 2019'da ortaya çıkan ve küresel bir pandemi durumu yaratan COVID-19 için çalışmalar halen devam etmektedir. Pandemi 20 Mart 2021 tarihi itibariyle dünyada 121.969.223 vaka ve 2.694.094 ölüme sebep olurken ülkemizde ise 2.992 .694 vaka ve 29.959 ölüme sebep olmuştur $(47,48)$. Ülkelerin imkanlarına göre salgını kontrol altına almak ve hastalık bulaşma riskini en aza indirmek için çalışmalar yapılmaktadır. Farklı merkezlerce üretilen aşısı bulunan COVID-19, yeterli aşılama yapılmasıyla toplumsal bağışıklık elde edilene kadar büyük bir tehdit olmayı sürdürecektir. Bu nedenle COVID19 tedavisi için yeni tedavi protokolleri arayışı sürmektedir, bunlardan birisi de mezenkimal kök hücre tedavisidir. Mezenkimal kök hücreler, immünolojik etkilerinden dolayı bu hastalığın iyileşmesinde rol oynayabilir. Birkaç klinik çalışmada mezenkimal kök hücre uygulamasını takiben iyi sonuçlar elde edilmiştir. İleride uygulanacak tedavilere ek olarak kök hücrelerin kullanımasının faydalı olma potansiyelinin yüksek olduğu düşünülmektedir.

Çıkar çatışması: Yazarlar çıkar çatışması beyan etmemişlerdir.

\section{Kaynaklar}

1. Nickbakhsh S, Mair C, Matthews L, Reeve R, Johnson PCD, Thorburn F, et al. Virus-virus interactions impact the population dynamics of influenza and the common cold. Proc Natl Acad Sci U S A. 2019; 116 (52): 27142-50.

2. Tang D, Comish P, Kang R. The hallmarks of COVID-19 disease. PLoS Pathog. 2020; 16 (5): 1-24.

3. Rodriguez-Morales AJ, Bonilla-Aldana DK, Balbin-Ramon GJ, Rabaan AA, Sah R, Paniz-Mondolfi A, et al. History is repeating itself: Probable zoonotic spillover as the cause of the 2019 novel coronavirus epidemic. Infez Med. 2020; 28 (1): 3-5.

4. Lu H, Stratton CW, Tang YW. Outbreak of pneumonia of unknown etiology in Wuhan, China: The mystery and the miracle. J Med Virol. 2020; 92 (4): 401-2.

5. Huang C, Wang Y, Li X, Ren L, Zhao J, Hu Y, et al. Clinical features of patients infected with 2019 novel coronavirus in Wuhan, China. Lancet. 2020; 395 (10223): 497-506.

6. Johnson M. Wuhan 2019 Novel Coronavirus - 2019-nCoV. Mater Methods. 2020; 10 (JANUARY): 1-5.

7. Gralinski LE, Menachery VD. Return of the coronavirus: 2019-nCoV. Viruses. 2020; 12 (2): 1-8.

8. Deng S-Q, Peng H-J. Clinical Medicine Characteristics of and Public Health Responses to the Coronavirus Disease 2019 Outbreak in China. J Clin Med. 2020 Feb; 9 (2): 575.; Feb; 9 (2): 575.

9. Su S, Wong G, Shi W, Liu J, Lai ACK, Zhou J, et al. Epidemiology, Genetic Recombination, and Pathogenesis of Coronaviruses. Trends Microbiol 2016 Jun; 24 (6): 490-502.

10. Domingo E, Perales C. Viral quasispecies. PLoS Genet. 2019; 15 (10): 1-20.

11. Zhou P, Yang X Lou, Wang XG, Hu B, Zhang L, Zhang W, et al. A pneumonia outbreak associated with a new coronavirus of probable bat origin. Nature. 2020; 579 (7798): 270-3.

12. Zhu N, Zhang D, Wang W, Li X, Yang B, Song J, et al. A Novel Coronavirus from Patients with Pneumonia in China, 2019. N Engl J Med. 2020; 382 (8): 727-33.

13. Chen Y, Liu Q, Guo D. Emerging coronaviruses: Genome structure, replication, and pathogenesis. J Med Virol. 2020; 92: 92.

14. Lu R, Zhao X, Li J, Niu P, Yang B, Wu H, et al. Genomic characterisation and epidemiology of 2019 novel coronavirus: implications for virus origins and receptor binding. www.thelancet.com. 2020; 395: 565.

15. Glowacka I, Bertram S, Muller MA, Allen P, Soilleux E, Pfefferle S, et al. Evidence that TMPRSS2 Activates the Severe Acute Respiratory Syndrome Coronavirus Spike Protein for Membrane Fusion and Reduces Viral Control by the Humoral Immune Response. J Virol. 2011 May; 85 (9): 4122-34.

16. Hu B, Ge X, Wang LF, Shi Z. Bat origin of human coronaviruses Coronaviruses: Emerging and re-emerging pathogens in humans and animals Susanna Lau Positive-strand RNA viruses. Virol J. 2015; 12 (1): 1-10.

17. Chan JF, Kok K. Correction to: Genomic characterization of the 2019 novel human-pathogenic coronavirus isolated from a patient with atypical pneumonia after visiting Wuhan (Emerging Microbes \& Infections, (2020), 9, 1, (221-236), 10.1080/22221751.2020.1719902). Emerg Microbes Infect. 2020; 9 (1): 540.

18. Letko M, Marzi A, Munster V. Functional assessment of cell entry and receptor usage for SARS-CoV-2 and other lineage B betacoronaviruses. Nat Microbiol. 2020; 5 (4): 562-9. 
19. Cascella M, Rajnik M, Cuomo A, Dulebohn SC, Di Napoli R. Features, Evaluation and Treatment Coronavirus (COVID-19). StatPearls. StatPearls Publishing; 2020 . PMID: 32150360; 1-56.

20. Liu DX, Fung TS, Chong KKL, Shukla A, Hilgenfeld R. Accessory proteins of SARS-CoV and other coronaviruses. Vol. 109, Antiviral Research. Elsevier; 2014. p. 97-109.

21. Pyle CJ, Uwadiae FI, Swieboda DP, Harker JA. Early IL-6 signalling promotes IL-27 dependent maturation of regulatory T cells in the lungs and resolution of viral immunopathology. PLoS Pathog. 2017;13(9):1-27.

22. Bennardo F, Buffone C, Giudice A. New therapeutic opportunities for COVID-19 patients with Tocilizumab: Possible correlation of interleukin-6 receptor inhibitors with osteonecrosis of the jaws. Vol. 106, Oral Oncology. Elsevier Ltd; 2020. p. 104659.

23. Rose-John S. Interleukin-6 family cytokines. Cold Spring Harb Perspect Biol. 2018 Feb;10(2).

24. Zayed M, lohara K. Immunomodulation and Regeneration Properties of Dental Pulp Stem Cells: A Potential Therapy to Treat Coronavirus Disease 2019. Cell Transplant. 2020;29:1-9.

25. Beniac DR, Andonov A, Grudeski E, Booth TF. Architecture of the SARS coronavirus prefusion spike. Nat Struct Mol Biol. 2006; 13 (8): 751-2.

26. Hoffmann M, Kleine-Weber H, Schroeder S, Mü MA, Drosten C, Pö S. SARS-CoV-2 Cell Entry Depends on ACE2 and TMPRSS2 and Is Blocked by a Clinically Proven Protease Inhibitor. Cell. 2020;181:271-80.

27. Arndt AL, Larson BJ, Hogue BG. A Conserved Domain in the Coronavirus Membrane Protein Tail Is Important for Virus Assembly. J Virol. 2010; 84 (21): 11418-28.

28. Schoeman D, Fielding BC. Coronavirus envelope protein: Current knowledge. Virol J. 2019;16(1):1-22.

29. McBride R, van Zyl M, Fielding BC. The coronavirus nucleocapsid is a multifunctional protein. Viruses. 2014; $6(8): 2991-3018$.

30. Lee RH, Pulin AA, Seo MJ, Kota DJ, Ylostalo J, Larson BL, et al. Intravenous hMSCs Improve Myocardial Infarction in Mice because Cells Embolized in Lung Are Activated to Secrete the Anti-inflammatory Protein TSG-6. Cell Stem Cell 2009; 2; 5 (1): 54-63.

31. Qin C, Zhou L, Hu Z, Zhang S, Yang S, Tao Y, et al. Dysregulation of immune response in patients with coronavirus 2019 (COVID-19) in Wuhan, China. Clin Infect Dis. 2020 Aug; 71 (15): 762-8.

32. Jiang D, Muschhammer J, Qi Y, Kügler A, De Vries JC, Saffarzadeh M, et al. Suppression of NeutrophilMediated Tissue Damage-A Novel Skill of Mesenchymal Stem Cells HHS Public Access. Stem Cells. 2016; 34 (9): 2393-406.

33. Braza F, Dirou S, Forest V, Sauzeau V, Hassoun D, Chesné J, et al. Mesenchymal Stem Cells Induce Suppressive Macrophages Through Phagocytosis in a Mouse Model of Asthma. Stem Cells. 2016 Jul; 34 (7): 1836-45.

34. Gao P, Yang X, Mungur L, Kampo S, Wen Q. SuppleAdipose tissue-derived stem cells attenuate acute lung injury through eNOS and eNOS-derived NO. Int J Mol Med. 2013 Jun; 31 (6): 1313-8.

35. Krasnodembskaya A, Samarani G, Song Y, Zhuo H, Su X, Lee JW, et al. Human mesenchymal stem cells reduce mortality and bacteremia in gram-negative sepsis in mice in part by enhancing the phagocytic activity of blood monocytes. Am J Physiol - Lung Cell Mol Physiol. 2012 May; 302 (10).

36. Khatri M, Richardson LA, Meulia T. Mesenchymal stem cell-derived extracellular vesicles attenuate influenza virus-induced acute lung injury in a pig model. Stem Cell Res Ther. 2018 Jan; 9 (1).

37. Behnke J, Kremer S, Shahzad T, Chao C-M, Böttcher-Friebertshäuser E, Morty RE, et al. MSC Based Therapies-New Perspectives for the Injured Lung. J Clin Med. 2020 Mar; 9 (3): 682.

38. Huppert LA, Matthay MA. Alveolar fluid clearance in pathologically relevant conditions: In vitro and in vivo models of acute respiratory distress syndrome. Front Immunol. 2017; 8 (APR): 1-6.

39. Shah TG, Predescu D, Predescu S. Mesenchymal stem cells-derived extracellular vesicles in acute respiratory distress syndrome: a review of current literature and potential future treatment options. Clin Trans Med. 2019; 8 (1): 25.

40. Golchin A, Farahany TZ. Biological Products: Cellular Therapy and FDA Approved Products. Vol. 15, Stem Cell Reviews and Reports. Humana Press Inc.; 2019. p. 166-75.

41. Atluri S, Manchikanti L, Hirsch JA. Expanded umbilical cord mesenchymal stem cells (UC-MSCs) as a therapeutic strategy in managing critically ILL COVID-19 patients: The case for compassionate use. Pain Physician. 2020; 23 (2): E71-84.

42. Manchikanti L, Centeno CJ, Atluri S, Albers SL, Shapiro S, Malanga GA, et al. Bone marrow concentrate (BMC) therapy in musculoskeletal disorders: Evidence-based policy position statement of american society of interventional pain physicians (ASIPP). Pain Physician. 2020; 23 (2): E85-131. 
43. Leng Z, Zhu R, Hou W, Feng Y, Yang Y, Han Q, et al. Transplantation of ACE2- Mesenchymal Stem Cells Improves the Outcome of Patients with COVID-19 Pneumonia. Aging Dis. 2020 Mar; 11 (2): 216.

44. Rogers CJ, Harman RJ, Bunnell BA, Schreiber MA, Xiang C, Wang FS, et al. Rationale for the clinical use of adipose-derived mesenchymal stem cells for COVID-19 patients. J Transl Med. 2020; 18 (1): 1-19.

45. Liang B, Chen J, Li T, Wu H, Yang W, Li Y, et al. Clinical remission of a critically ill COVID-19 patient treated by human umbilical cord mesenchymal stem cells: A case report. Medicine (Baltimore). 2020 Jul; 99 (31): e21429.

46. Shetty AK. Mesenchymal stem cell infusion shows promise for combating coronavirus (COVID-19)-induced pneumonia. Aging Dis. 2020; 11 (2): 462-4.

47. WHO Coronavirus (COVID-19) Dashboard | WHO Coronavirus Disease (COVID-19) Dashboard [Internet]. [cited 2021 Mar 20]. Available from: https://covid19.who.int/

48. Covid19 [Internet]. [cited 2021 Mar 20]. Available from: https://covid19.saglik.gov.tr/ 